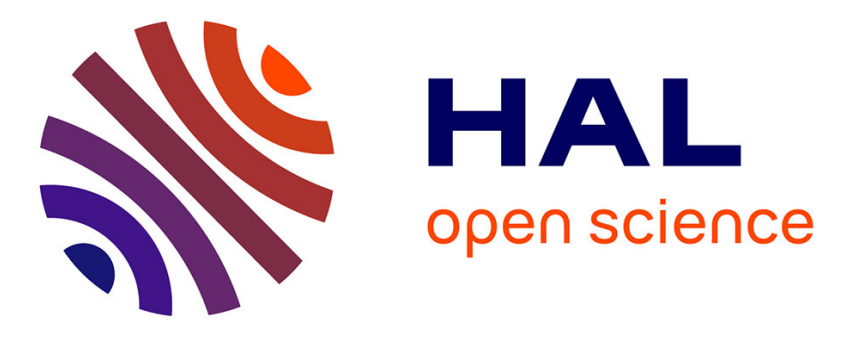

\title{
Groundwater Resources Use and Management in the Amu Darya River Basin (Central Asia)
}

Shavkat Rakhmatullaev, Frédéric Huneau, Jusipbek Kazbekov, Philippe Le

Coustumer, Jamoljon Jumanov, Bouchra El Oifi, Mikael Motelica-Heino, Zbynek Hrkal

\section{To cite this version:}

Shavkat Rakhmatullaev, Frédéric Huneau, Jusipbek Kazbekov, Philippe Le Coustumer, Jamoljon Jumanov, et al.. Groundwater Resources Use and Management in the Amu Darya River Basin (Central Asia). Environmental Earth Sciences, 2010, 59, pp.1183-1193. 10.1007/s12665-009-0107-4 . insu00442903

\section{HAL Id: insu-00442903 \\ https://hal-insu.archives-ouvertes.fr/insu-00442903}

Submitted on 23 Dec 2009

HAL is a multi-disciplinary open access archive for the deposit and dissemination of scientific research documents, whether they are published or not. The documents may come from teaching and research institutions in France or abroad, or from public or private research centers.
L'archive ouverte pluridisciplinaire HAL, est destinée au dépôt et à la diffusion de documents scientifiques de niveau recherche, publiés ou non, émanant des établissements d'enseignement et de recherche français ou étrangers, des laboratoires publics ou privés. 


\section{Groundwater Resources Use and Management in the Amu Darya River Basin (Central Asia)}

Shavkat RAKHMATULLAEV ${ }^{1,2}$, Frédéric HUNEAU ${ }^{2 \dagger}$, Jusipbek KAZBEKOV ${ }^{3}$, Philippe LE COUSTUMER $^{2}$, Jamoljon JUMANOV ${ }^{4}$, Bouchra EL OIFI², Mikael MOTELICA-HEINO5 Zbynek HRKAL ${ }^{6}$

${ }^{1}$ Tashkent Institute of Irrigation and Melioration (TIIM), 39 Kary Niyazov Street, Tashkent 100000, Uzbekistan, rakhmatullaev@rambler.ru

${ }^{2}$ University of Bordeaux-1, GHYMAC Géosciences Hydrosciences, Faculty of Earth Sciences, B18 avenue des Facultés, 33405 Talence, France, f.huneau@ghymac.ubordeaux1.fr, plc@lnet.fr, bouchra.eloifi@u-bordeaux1.fr

${ }^{3}$ International Water Management Institute (IWMI), Apt.123, House 6, Murtazaeva Street Tashkent 100000 Uzbekistan, j.kazbekov@cgiar.org

${ }^{4}$ Institute of Hydrogeology and Engineering Geology (HYDROENGEO), 64 Khodjibaev Street, Tashkent 100041, Uzbekistan, hydrouze@rambler.ru

${ }^{5}$ University of Orléans, Institute of Earth Sciences (ISTO), 1A rue de la Ferollerie, 45071 Orléans Cedex 2, France, mikael.motelica@univ-orleans.fr

${ }^{6}$ Charles University, Institute of Hydrogeology Engineering Geology and Applied Geophysics, Albertov 6, 12843 Prague, Czech Republic, Zbynek_Hrkal@vuv.cz

\section{Corresponding author:}

${ }^{\dagger}$ Frédéric HUNEAU, University of Bordeaux-1, GHYMAC Géosciences Hydrosciences, Faculty of Earth Sciences, B18 avenue des Facultés, 33405 Talence, France Tél: +33.5.40.00.88.41 ; Fax: +33.5.40.00.31.13 ; e-mail:f.huneau@ghymac.u-bordeaux1.fr 


\begin{abstract}
This paper analyses groundwater resources use and management in the socioeconomic context of the Amu Darya River Basin which covers part of the following landlocked Central Asian countries: Afghanistan, Tajikistan, Turkmenistan and Uzbekistan. These agrarian nations for sustaining their vital agricultural productions started to use groundwater during the recent drought years (1998-2001) because of its relatively good quality and quantity and as an alternative to highly mineralized surface waters. Present extent of groundwater resources use is discussed with consideration to their reserves, quality, and institutional management and transboundary aspects within the basin. After the collapse of the centralized water resources management system and infrastructure of the former Soviet Union, new underdeveloped systems are being practiced over the whole Amu Darya River Basin. The critical situation of groundwater management in Afghanistan is also discussed.

The document attempts to document the management and use of groundwater in the Amu Darya Basin and present time management realities, with fragmented and weak national and regional regulation on groundwater. Special attention is given to groundwater resources in irrigated agriculture, which increased use in all countries of the basin is due to quick access to underground resources and relatively good quality and quantity.
\end{abstract}

\title{
Key words
}

groundwater, aquifer, water management, Amu Darya, Central Asia 


\section{INTRODUCTION}

In Central Asia, the Amu Darya River Basin (ADRB) which namely covers part of Afghanistan and the former soviet republics of Tajikistan, Uzbekistan and Turkmenistan, groundwater resources are becoming an alternative source of supply for irrigated agriculture and livestock ranching especially in the events of recent droughts and in the context of highly contaminated surface waters due to high levels of salts and pesticides coming from irrigated lands. Due to their climatic characteristics, economic development strategies and geopolitical situation, ADRB countries have been experiencing everlasting competition over water resources. Mostly arid, these agrarian countries pursue their own development and integration into the global community through expanding irrigated lands, growing cash crops such as rice and wheat for meeting their domestic food security but also to export a large part of some productions like cotton.

Groundwater resources were not widely used for irrigated agriculture in Central Asian Republics (CAR) during the soviet period due to sufficient amount of surface water, reliable water supply and irrigation infrastructure delivered to the farmers. Thus the groundwater resources were used primarily for livestock sector and very site-specific purposes for example drinking water supply in both urban and rural areas. During the pre-independence period, water allocation and irrigation system infrastructures were well maintained and operated with massive funding coming from the central government.

Since the independence of the CAR, the situation has changed dramatically in terms of institutional, political and technical systems. Political transition from planned economy to market has introduced "new" concepts like land tenure, water rights and different kinds of ownership. The institutional changes are described as transition from former state collective farms kholkhoz and sovkhoz into smaller forms of present private farms. But many farmers were not in the capacity to pump and irrigate lands on an individual basis. 
In a very different situation, Afghanistan has traditionally relied on surface water and groundwater springs and karezes in irrigated agriculture. According to the estimates of International Water Management Institute (IWMI), the share of groundwater irrigation of the cultivated area is $11,5 \%$ of the total in Afghanistan (Shah, 2007). During recent drought years (1998-2001), the use of deeper groundwater, abstracted via pumped dug wells and boreholes has increased rapidly. Private farmers have drilled many of these new wells and boreholes, and in some areas, groundwater abstraction rates are already exceeding, or will soon exceed, sustainable groundwater resources (Banks and Soldal, 2002 ; Uhl, 2003 ; Masood and Mahwash, 2004).

Groundwater overdraw is not everywhere the case in ADRB but the water drought experienced in 1998-2001 have encouraged people to consider groundwater as an alternative to declining surface water resources. Then many farmers, who could afford, started to exploit groundwater for the irrigation purposes and mainly to sustain the production during low flow periods and maintain the salinity of irrigation water compatible with agriculture. In addition it should be stated that from the quantitative point of view shallow groundwater is a reliable source of water and people who are distant from source of surface water can obtain it easily for the watering of their fields.

The main goal of this paper is to document and analyze the new realities of the groundwater use both quantitatively and qualitatively in the basin in current settings and to overview main issues and perspectives for sustainable interstate use of groundwater resources as a strategic potential in reducing the poverty in ADRB countries.

\section{AMU DARYA RIVER BASIN CHARACTERISTICS}

\section{Physiography}


The endoreic basin of Amu Darya River is located in the inner part of the Eurasian Continent (Fig. 1). The catchment area comprises 534,739 $\mathrm{km}^{2}$ (Water Resources of USSR, 1971). $61 \%$ of the catchment area lies on the territory of the former Soviet Union and flows through the territories of the new independent states of Tajikistan, Uzbekistan, and Turkmenistan and 39\% on the territory of Afghanistan (Water Resources of USSR 1971; Uhl 2003).

The Amu Darya River is formed by the confluence of the Pyanj and Vash Rivers in the Pamir Mountains and discharges into the Aral Sea after a run of 2550km. Two Rivers, Zaravshan and Kashkadarya are related to Amu Darya in term of water catchment characteristics but do not discharge into the Amu Darya River (Mirzaev 1974; Masood and Mahwash 2004). The Amu Darya watershed is divided into two unequal parts, a large Northwestern part where plains are dominant and elevations not greater than $200 \mathrm{~m}$ and a smaller South-eastern part characterized by high mountain ranges of 5000-6000m of Central Pamir and Tian Shan. The presence of these high mountain ranges facilitates the formation of great water courses despite the very arid conditions of the region since it can accumulate atmospheric moisture, and behave as a huge feeding reservoir. The major part of the territory of the ADRB is composed of desert-steppe areas. The juxtaposition of mountains and deserts exerts a great influence upon the hydrogeological conditions, thus favouring the formation of considerable groundwater resources in a number of arid regions. The proximity of mountains and deserts in Central Asia determines the existence of two subtypes of groundwater formation in arid conditions: autochthonous and allochthonous (Ostrovsky 2007). The autochthonous subtype is developed in regions not influenced by mountainous systems and is characterized by groundwater formation from in situ water resources, and mainly from precipitation. The allochthonous subtype is typical of deserts where groundwater is formed under the influence of mountainous systems. It is commonly held that arid zones are 
characterized by the presence of basins that have no runoff to the ocean and where all precipitation is used up through evapotranspiration. However, if arid zones are considered within their climatic boundaries, then the balance of precipitation and evaporation cannot be true, as the total amount of evaporation also includes evaporation of both surface runoff and groundwater discharge from mountainous humid regions (Ostrovsky 2007).

\section{Hydroclimatology}

The north-western plain of Central Asia is characterized by very hot summer (mean July temperature about $25.5^{\circ} \mathrm{C}$ ) and cold winters (mean January temperature about $2.4^{\circ} \mathrm{C}$ ). The ADRB is open to the dry air masses formed in Antarctic and Siberia coming from the North. As they are blown towards Western and Southern parts of the basin these cold air masses are heated and then can encounter tropical air masses coming from the South. Unstable winters over the region are resulting from this mixing front between dry cold air masses and tropical warm air masses (Aizen et al. 2001).

The basin is characterized by uneven distribution and quantity of precipitation. The average mean annual precipitation over the basin is about 170mm (Shultz 1949), with great contrast between north-western steppes (100mm/year) and mountainous areas of the Southeastern (1000mm/year). The important role of mountains and glaciers should be pointed out as these areas can store precipitation as snow and ice and deliver it through summer melting to rivers and associated alluvial aquifers during dry season (July and August). In average 96\% of the basin area receives approximately less than 300mm/year (Schultz 1949) and most of the rainfall occurs in winter and spring from December to April.

The dominant process in this very arid region is evapotranspiration which can potentially amount to 1500-2000mm/year (Letolle and Mainguet 1993, Nezlin et al. 2004) and is responsible of the loss of great volumes of water.

\section{Hydrogeology}


The region is characterized by very complicated hydrogeological conditions. At first, the complex geological history of the Pamir and Tian Shan Mountainous area is responsible for a huge diversity in term of aquifer and water bearing sediments. These regions are composed of Palaeozoic, Mesozoic and Cenozoic formations and significant shallow groundwater resources are located in valleys, where 10 to $100 \mathrm{~m}$ thickness deposit of semi consolidated coarse to medium Quaternary sediments have accumulated. In the piedmont area fresh confined groundwater can be found in the peripheral parts of Quaternary debris cones. Deeper aquifers in carbonate rocks (depths from $700-800 \mathrm{~m}$ up to $1,000-1,200 \mathrm{~m}$ ) contain thermal water, widely used in Tajikistan and Uzbekistan for medicinal purposes and bottled as table mineral water (Shultz 1949).

Plains region of the ADRB are covered by alluvial sand, loam and clay dating from the Quaternary and Pliocene and that can be interstratified, giving birth in some places to confined or semi-confined aquifers. Groundwater in these surface formations are strongly hydraulically connected to Amu Darya River and mainly recharged by losses of rivers (allochthonous river run-off), irrigation canals and irrigated fields. A lot of shallow aquifer are salinized (1-10 g/l) or engaged into salinization processes. Salinization results from agricultural practises but is also related to the sodic nature of soil like solonetz and solontchaks. It must be noted that groundwater mineralization tends to decrease with depth (Ostrovsky 2007) and that mineralization processes are strongly correlated to groundwater level rise caused by irrigation.

Confined aquifers can be found in the deep Cretaceous sandstone formations of the Aral Sea area and provide artesian waters. In some parts these deep groundwater can show high mineralization which prevent them from any use. Mineralization can even reach values around 25-50 g/l at depth close to the Aral Sea region (Water Resources of USSR 1971). 
In the Soviet times, groundwater resources were explored for the purpose of irrigation. Although they proved to be abundant, the primary focus was placed on the use of surface water. In Central Asia, groundwater constitutes a resource of fresh water that is comparable or exceeds surface waters in terms of volume. In many places this renewable resource can be effectively utilised with simple wells, which may, particularly, work as artesian wells in the lower parts of mountain slopes and mountain valleys.

\section{GROUNDWATER RESERVES AND EXTRACTION}

\section{Groundwater reserves and use}

Groundwater resources can be classified according to their recharge processes, two main classes can be distinguished: i) groundwater formed under natural conditions in the mountain zone and catchment areas by infiltration of rainfall (autochthonous groundwater) ii) groundwater formed from the infiltration losses from irrigated areas in the rest of the ADRB (allochthonous groundwater). The total regional groundwater reserves are estimated to $25 \mathrm{~km}^{3} /$ year (Mirzaev 1974) which represents about $58 \%$ of the Aral Sea Basin reserves (Table 1)

Groundwaters and surface waters are strongly hydraulically connected one to another, and according to an established system in the ADRB groundwater availability is characterized by the so called "natural recharge capacity" which can be considered as the regional operational reserve (Water resources of USSR 1971). This is a potential yield of each aquifer, which under the pressure of anthropogenic factors can be reasonably tapped in order to satisfy the needs. This is based on both the existing installed pump capacity and the level of knowledge of the aquifer recharge characteristics. "Approved capacities" confer the right to design and construct new withdrawal points (Table1). 
Aquifers in Uzbekistan and Tajikistan are relatively the most intensively exploited. About 99\% of approved groundwater reserves are used in Uzbekistan, whereas in Tajikistan and Turkmenistan only about $30-40 \%$ are used for various purposes (Table 1 ). This can be explained by both intensive groundwater abstraction infrastructure in Uzbekistan with funding from the central government in irrigated areas and by uncontrolled water extraction by local farmers and the population in more isolated areas which tend to tap the aquifers to the maximum of their possibilities.

In Turkmenistan, about 134 large groundwater bodies can been identified and used for various needs (Khatamov 2002; Orlovsky and Orlovsky 2002). The total intake of groundwater resources varies from $4.7-6.7 \mathrm{~km}^{3} /$ year out of which $45 \%$ is used for drinking supply, 30\% for irrigation and rest for livestock ranching. Groundwater from the first waterbearing horizon serves as a major water source in the desert areas. In 1994, according to different sources, there were from 5,695 to 6,138 water wells and up to 619 boreholes, which supplied water to about 68\% of pastures (Babaev and Kolodin 1995; Babaev and Kolodin 1997). In the recent years, a number of new water wells was built, but at the same time the old ones were destroyed. So the exact number of functioning wells and boreholes is now unknown.

In Tajikistan, many groundwater bodies can be identified in the very complex structural framework of the country but all limited in term of extension. According to the National Hydrometeorological Agency the total amount withdrawn annually is about 2,372 $\mathrm{km}^{3}$ in 2004 (Table 2) without negative impact since the approved reserved are about 6,972 $\mathrm{km}^{3}$ (Salimov 2001). About $40 \%$ of groundwater is used for irrigation and about $49 \%$ for domestic drinking supply. In 1994, the total numbers of wells was 4795 and out of which 511 are wellspring and 4358 are operational wells (Orlovsky and Orlovsky 2002). 
In Uzbekistan, around 94 major aquifers can be identified with a total groundwater volume of about $18.9 \mathrm{~km}^{3}$, this includes $7.6 \mathrm{~km}^{3}$ with mineralization of up to $1 \mathrm{~g} / \mathrm{l}$ and 7.9 $\mathrm{km}^{3}$ with mineralization from 1 to $3 \mathrm{~g} / \mathrm{l}$. $85 \%$ of the groundwater resource is recharged from surface water and only $1 / 3$ is formed on the territory of neighboring countries and which could be called "transboundary" groundwater resources (Mirzaev 1974; Borisov 1990). The percentage of groundwater used in irrigation amounted to $6.4 \%$ of the total irrigated land in Uzbekistan. Limits to groundwater abstraction for each aquifer in Uzbekistan have been established in order to avoid significant consequences to surface flow reduction. This quantity is estimated at $6.8 \mathrm{~km}^{3} /$ year for Uzbekistan. However, the actual groundwater abstraction is slightly superior (estimated at $7.5 \mathrm{~km}^{3} /$ year) and thus tends to lead to a surface flow reduction (Kazbekov et al. 2007).

The great aquifers or regional operational reserves of Uzbekistan have been primarily identified according to drinking water standards. For example, for the 1965-1995 period the fresh drinking groundwater resources in Uzbekistan have decreased from 471 to $294 \mathrm{~m}$ /sec and comprise only $34 \%$ of total groundwater resources compared to the $56 \%$ of total groundwater resources it represented in the past (Borisov et al. 2002). In 2001 total extraction of groundwater decreased by $4.9 \%$ and irrigation by $10.4 \%$ in the Uzbek part of the ADRB in comparison to 1995. The observed decrease in extraction is due to the reduction of operation hours of wells, worn out of pumping systems and bad condition of wells. In comparison with 1995 the total withdrawal decreased by $38.7 \%$ (Borisov et al. 2002).

On the other hand, groundwater reserves increased from 844 to $853 \mathrm{~m}^{3} / \mathrm{sec}$ in Uzbekistan from 1995 to 2001(Borisov et al. 2002). The increase is explained by the development of irrigated lands. As a result of infiltration of water losses, the level of groundwater of unconfined aquifer began to rise also entailing the dissolution of salts contained in the upper part of soil profiles (Kitamura et al. 2006; Northey et al. 2006). This is 
particularly true in the lower reaches of Amu Darya River where the groundwater resources were at 15-20m depth in 1980s and started to rise 1-1.5m depth in early 2000 (Borisov et al. 2002).

The surface of irrigated areas with high groundwater table level has increased by $21 \%$ in ADRB (Table 3) that is to say from 1.29 million ha in 1990 to 1.56 million ha in 1999 in CAR (UNDP 2007).

After the drought of 1998-2001 groundwater use has increased in lower reaches of ADRB. For instance, the Government of Uzbekistan has issued special decrees to overcome the consequences of the drought. The main purposes of the decrees were to drill 2,600 shallow wells in rural districts for population needs. The second purpose of these measures was to repair old wells that were used for both agriculture and drinking water supply (Kuchuhidze et al. 2003).

\section{Groundwater extraction methods}

Groundwater extraction methods in Central Asia are much contrasted and can go from the traditional karezes systems in Afghanistan to modern pumping plants in Uzbekistan.

Karezes are human-made underground channels common in Afghanistan. They are often very old, having been constructed several hundred years ago. They are typically located in the foothills or mountain areas, but can be constructed anywhere where the water table is relatively shallow and where there is a consistent slope of the terrain. Karezes essentially skim water off the top of the water table. This means that, in effect, it is practically impossible to overexploit an aquifer using karezes (Fuchinoue et al. 2002). On the negative side, they are extremely vulnerable to even relatively small drops in the water table caused by climatic factors or pumping of nearby wells. Karezes may be used for irrigation and drinking water. Due to decline in water table related to the current drought in Afghanistan, flows available for irrigation from karezes have become inadequate in many areas and farming viability is 
suffering. Thus dug wells and boreholes are typically drilled at shallow depth (up to 20m) in Neogene and Quaternary sediments (Banks and Soldal 2002). They may be used for drinking water or for irrigation purposes and most of the time fitted with hand pump. In some areas, artesian aquifer may exist at depth. In this case, pumps are not required in boreholes; they simply overflow under their own pressure. In the Mazrah area of Guzara District (Herat), private irrigation boreholes drilled to $60-65 \mathrm{~m}$ deep encounter artesian resources of fresh groundwater. Typical yields of about 5l/sec flow uncontrolled 24 hours/day from these boreholes. Such uncontrolled overflow is extremely undesirable from a water resource point of view (Banks and Soldal 2002). For irrigation, most of lands were irrigated either by surface water or by groundwater from karezes or natural springs. This situation is rapidly changing. Lift irrigation is new technology and, although in overall terms it still accounts for a relatively modest share of total irrigated land, its use is growing explosively.

For the CAR the major share of groundwater extraction is coming from borehole and dug wells thanks to heavy equipments developed during the soviet period and still operating in many places. According to Uzbekistan Research Institute on Hydrogeology and Engineering Geology (HYDROENGEO) and Ministry of Agriculture and Water Resources of Uzbekistan, the extraction of groundwater is made mainly from borehole but at very different depth and with many kinds of design, mainly inherited from Russian technologies. Extraction of shallow groundwater up to $6.0 \mathrm{~m}$ is operated manually, deeper unconfined aquifer (30150m) from Quaternary are exploited with electrical submersible pumps of varying capacity of 10-70l/sec. (Borisov 1990).

\section{Cost of groundwater extraction}

According to the HYDROENGEO Institute the use of groundwater is not economically profitable for irrigation due to its high extraction costs and economic inefficiency in Uzbekistan (Mirzaev 1974; Borisov 1990). The global production cost per $1 \mathrm{~m}^{3}$ 
of groundwater is about 0.5-1.0 US\$ (UNDP 2007). Input per $1 \mathrm{~m}^{3}$ of surface gravity irrigation for a farmer is estimated to be $0.13-0.15$ US\$, and in the areas of pumped irrigation is about 0.3 US\$ (UNDP 2007). Thus, production cost in the case of groundwater exploitation is clearly higher than that of surface water exploitation.

However the use of groundwater resources for irrigation purposes is justified in water scarce conditions and in special places of the territory of Central Asia. For instance in the ADRB by 2003 there approximately 27,000 boreholes were drilled to counterpoise the pernicious effects of the drought, with depth varying between 50-500m with a cost of drilling for one borehole ranging within 500-2000 US\$.

Decentralized water supply of rural population, especially downstream the Amu Darya River, is provided by unconfined groundwater resources coming from shallow wells of 15$20 \mathrm{~m}$. Extraction of groundwater is manually operated with hand pumps which cost is about 100 US\$ each. The drilling and equipment of the tube with steel pipes can reach about 100150 US\$ in unconsolidated sediments like sands (UNDP 2007).

In Afghanistan, according to Banks and Soldal (2002), dug wells are typically 3-4 times cheaper than boreholes. Typical drilling prices in Afghanistan are 5-6 US\$/m in soft strata, $12 \mathrm{US} \$ / \mathrm{m}$ in hard strata. In some parts of Afghanistan, where the demand is high, prices can reach 18-20 US\$/m (Banks and Soldal 2002) and are thus dedicated to a very limited number of people who can afford such prices.

\section{GROUNDWATER AND AGRICULTURE}

\section{Massive irrigation}

Irrigation in Central Asia and particularly in Uzbekistan relies on a system of pumps and canals which is among the most complex in the world. Cotton and wheat are the major crops in the ADRB followed by maize, vegetables and fruits. As previously said with annual 
rainfall of $100-300 \mathrm{~mm}$, the CAR's climate is that of the dry mid-latitude desert, with a continental climate that is characterized by hot summers and cold winters. Thus, agricultural production in Central Asia, is predominantly based on irrigation, which makes irrigation water supply and management the major factors limiting crop yields in the region (Ibragimov et al. 2007).

Agriculture is the dominant sector of the economy in the ADRB countries, employing from 44 up to $80 \%$ of the workforce (Table 4). This sector contributes to the basin countries Gross Domestic Product (GDP) from 16 up to 36\% with an average of 26\% over the basin. All of the ADRB countries are landlocked with arid climatic conditions and agricultural lands are heavily dependent on irrigation to insure acceptable production. Almost all of the agricultural lands are irrigated in Turkmenistan, while the average is around $75 \%$ in the other basin counties. Climatic conditions and recent droughts coupled with increased deteriorating quality of surface water prone water users to use more groundwater resources. The Table 4 summarizes the main characteristics of agriculture and irrigation in the ADRB countries.

In Afghanistan, the estimated annual groundwater volume used for irrigation is minimal $\left(1,0 \mathrm{~km}^{3} /\right.$ year $)$ in comparison with the groundwater recharge estimate $\left(2,97 \mathrm{~km}^{3} /\right.$ year $)$ indicating a significant surplus of groundwater reserves in this part of the ADRB and the real potential for future development of groundwater resources for irrigation (Uhl 2003). The total withdrawal of groundwater in Uzbekistan for 2003 is about $2 \mathrm{~km}^{3} /$ year and it is used at $40 \%$ for irrigation purposes (Kazbekov et al. 2007). In Turkmenistan, agriculture is almost impossible without irrigation as shown in Table 4 and as a consequence this country is one of the most impacted by pernicious effects of lift irrigation. From 1986 to 1998 strong rise in the water table was recorded with an increase from 7 to $41 \%$ in the surface of farming land with groundwater level less than $2 \mathrm{~m}$. 
In Tajikistan, the structure of agriculture is still heavily centralized and big collective farms are operating complex wells and irrigation systems. In 2000 there were roughly 1000 operational boreholes and numerous wells that totaled $4 \mathrm{~km}^{3} / \mathrm{sec}$ discharge mainly used for irrigation purpose. According to Salimov (2001) about 30,000ha of lands were irrigated with groundwater resources.

\section{Livestock Rearing}

In the Uzbek desert and mountain zones of the ADRB, numerous small settlements can be found. These territories are part of pasturelands. The mountain pasturelands have available groundwater resources but in most cases in poor conditions from pollution and contamination point of view. The livestock rearing under the desert conditions is off course

limited by the water supply availability even if in general, water supply of pasturelands requires very little quantity of water (from 10 to $25 \mathrm{~m}^{3} /$ day) for cattle watering ponds (Babu and Toshmatov 2000).

In Tajikistan, water supply of pasturelands for livestock ranching is supplied by both surface and groundwater resources. The vast areas of the foothills of the Central Tajikistan, plains of Pamir, and South-Tajik depression are rich winter pasturelands, the groundwater reserves can here supply millions of animals (Babu and Toshmatov 2000). At present time, just a limited part of available pasturelands is used for ranching alongside of streams and large springs.

In Turkmenistan about 5,200 wells, 50 boreholes, 330 springs are used to water the cattle. We must also point out the use in this country of more than 600 takyrs as collectors of atmospheric precipitation (Orlovsky and Orlovsky 2002).

\section{GROUNDWATER QUALITY}


The two major land quality problems in the ADRB are the interrelated issues of salinity and waterlogging caused by high groundwater levels, only $50 \%$ of the irrigated land is classed as non-saline (Banks and Soldal 2002). In the upper reaches of the ADRB, less than $10 \%$ of the land is saline or highly saline, while downstream (especially in Karakalpakstan) about $95 \%$ of the land is saline, highly saline or very highly saline. Salinity is closely related to drainage conditions. Moreover, a reduction in the quantity of water allocated to each farm, lower water quality, and the decay of companies responsible for maintaining the drainage network have resulted in increased salinization. Though loss of crop production due to soil salinization is important but salinized lands are generally still cultivated since no alternatives are available at present time (Heaven et al. 2002).

Less than $10 \%$ of the CAR's groundwater volume has a salinity level less than $1 \mathrm{~g} / \mathrm{l}$, equivalent to the highest quality irrigation water (FAO 2007). Overall, most groundwater has salinity levels between $1-3 \mathrm{~g} / \mathrm{l}$ with approximately $15 \%$ showing values between $3-5 \mathrm{~g} / \mathrm{l}$ and nearly 27\% having salinities > 5g/l (Chembarisov and Bakhritdinov 1989; O’Hara 1997; Gadalia et al. 2005).

In Uzbekistan, the regional operational groundwater reserves in 2003 comprised 9.17 $\mathrm{km}^{3} /$ year out of which groundwater with mineralization of $1.0 \mathrm{~g} / \mathrm{l}$ constitutes only around $30 \%$ and the rest for groundwater of 1 to $5 \mathrm{~g} / \mathrm{l}$.

Shallow groundwater sources have became increasingly salinized in the lower Amu Darya River in 2001. Several bore and open wells that were used as potable water supply sources have been recently abandoned because of increased salinity preventing any drinking use. Many wells were also recharging much more slowly than in the recent past and providing lower yields. As a consequence queues at wells were increasing and the amount of water available for daily withdrawal was decreasing at many sites (Medecins Sans Frontieres 2001). 
The dramatic change in the quality of groundwater resources observed in some place of the basin is linked to irrigation and melioration of lands; and reallocation and extraction of river flow (especially since 1965). Discharge of collector-drainage water into the river systems, its re-use and chemization of agriculture has led to regional pollution of unconfined groundwater resources by salts, nitrates and pesticides (Papa et al. 2004). Such water consumption patterns are well reflected in temporal changes in groundwater depth and salinity, which both showed a rapid increase in the late 1990s. The overall spatial distribution of groundwater salinity shows also strong spatial association with the type of aquifer rock and with the distance from the river along the main irrigation canals (Ibragimov et al. 2001). Coarser sediments showed a higher groundwater salinity than finer sediments. Pollution of groundwater occurs progressively from upstream to downstream along river stream. The mineralization of shallow groundwater in upstream of Amu Darya River is about 1-3g/l and in midstream and downstream it can increase up to 5-20g/l (Crosa et al. 2006a; Crosa et al. 2006b). This increase is the direct expression of the intense development of irrigation and drainage systems for the last 40 years and the consecutive mobilization of large amounts of salts already present in soils or added via agricultural practises.

In the whole ADRB man-caused influence have lead to pollution and to decrease of groundwater resources and operational reserves of fresh groundwater resources in average, for the last 30 years, by $0.17 \mathrm{~km}^{3} /$ year or in total by $5.1 \mathrm{~km}^{3}$ in Uzbekistan (Borisov 1990). Contamination levels registered in both surface and groundwater are so high that it is not possible to count on any natural purification process from percolation and infiltration of groundwater through the soil (UNDP 2007). Despite of this fact, farmers are forced to continue to use groundwater for agriculture, domestic, livestock and drinking purposes since no other water resources can be exploited. 
In lower the Amu Darya (part of Uzbekistan and Turkmenistan), the groundwater quality is also deteoriated in rural area due to very poor sewage systems. Traditionally all rural households have their toilets in close vicinity (10-30m away) from their houses and as a consequence shallow groundwater is very often contaminated by sewage.

Due to this reduction of high-quality water resources by 30-40\% compared to 19651970, the government of Uzbekistan undertakes extreme measures involving the creation of highly protected territories of groundwater resources with the aim of improvement of groundwater quality. With limited use of manure and pesticides and respectful development of local industry, these measures will tend to regulate and to reduce the water use in the national economy. These measures also include the renovation of the available wells which are very often in bad condition, the construction of new wells and the installation of new efficient pumps and efficient conveyance systems.

\section{TRANSBOUNDARY GROUNDWATER ISSUES}

\section{Problems coming from groundwater sharing}

Groundwater regimes and quality are determined both by natural factors and by the level of abstraction, it doesn’t depend on administrative boundaries (UNESCO 2001). As such, the management of internationally shared groundwater is of special importance in the ADRB (Struckmeier et al. 2006). Transboundary groundwater is assumed to include: groundwater aquifers which are located in two or more countries; and groundwater aquifers which are used in combination with surface water, and for which changes in extracted volumes may lead to changes in surface water quantity and use.

The combine use of both groundwater and surface water can be beneficial where long term sustainable groundwater extractions (not exceeding the natural recharge) replace scarce surface water resources (Zaisheng et al. 2008). However, if groundwater aquifers are not 
properly managed, many negative effects may occur: rise of groundwater levels and deterioration of soil conditions; local draw-down of groundwater levels around extraction points thus reducing surface water availability; pollution of aquifers because of human activities such as mining, treatment of industrial waste water, cattle-breeding; and overexploitation and long term damage to the groundwater potential.

These effects have local impacts, which may extend to the territories of neighbouring states. Often, measures which provide positive effects on the territory of one country like irrigation of new areas, canal construction, and public water supply development, lead to negative effects in adjacent countries and preventive measures in the affected states may be expensive and may take several decades to become effective, essentially due to political reasons.

About $30 \%$ of the 338 aquifers of the ADRB area are international, but they represent the majority of the extracted groundwater. The main international aquifers areas include the area around the Tuyamuyn reservoir and its supply canals between Turkmenistan and Uzbekistan; the piedmont zone in the Hungry Steppe with shared aquifers between Tajikistan and Uzbekistan; and aquifers on the border between the Kashkadarya oblast of Uzbekistan and the Lebab velayat of Turkmenistan. Obviously, conflicts may arise for many reasons in these regions. The main ones are the lack of proper groundwater accounting and registration of installed pumps and the lack of proper groundwater assessments, both in the design studies and in practical operations.

Groundwater response times generally include a delay of 1 to 2 years, and for some areas even of 3,5 , or 10 years or even sometimes centuries or millennia for confined resources (Huneau et al. 2001; Kazbekov et al. 2007). It is then difficult to establish the direct influence of groundwater exploitation development projects without good quality preimplementation observations. In the absence of proper management measures, special 
research is then needed to evaluate the consequences; it is usually carried out by the damaged party when the negative effects are already clearly showing. In the ADRB most of the problems are arising from the absence of proper regulations (limits) of groundwater withdrawal, in particular during dry years and in situations where over-extraction affects aquifers in neighbouring states or has an impact on transboundary rivers. A key problem is the lack of legal documents and international agreements to:

i) determine responsibilities when problems arise;

ii) establish the rights of reimbursement of the damaged party;

iii) require negative effects to be reversed;

iv) require inspection of pumping installations.

\section{Lack of institutional management of groundwater}

It should be stressed out that, withdrawal and discharge of international groundwater and drainage water, which are a main source of potential conflicts, require cooperative regulation and management within the whole Aral Sea basin. The development of a set of management measures should thus be considered, to reduce the negative influence of multiple uses of groundwater and drainage water, to be submitted to the Interstate Commission for Water Coordination (ICWC) for analysis and further preparation for decision making on the evaluation of the areas and size of shared aquifers and drainage water catchments; transboundary problems should be specified and proposals prepared to share the management of international groundwater.

Apart form the ICWC whose role is to organise international water management within the watersheds of Amu Darya and Syr Darya Rivers, almost no structure is dedicated to groundwater. Table 5 summarizes the main structures in charge of groundwater management in the different countries of the ADRB. As previously said, the extreme fragmentation and dilution of responsibilities shown in Table 5 is in clear disfavour with a proper and concerted 
groundwater management. The situation in Afghanistan is particularly critical since there is no regulatory framework for controlling and managing groundwater resources. In the literature, it is documented that the Ministry of Mines and Industry is the state responsible authority. But in practice, however, the ministries lack the resources and technical expertise to adequately manage the resources for which they have responsibility. There also appears to be no effective system of permits or licensing drilling or water abstraction in this country. In this regulatory vacuum, the United Nations and some nongovernmental organisations have accepted some responsibility for water resources.

In the CAR, there are established frameworks for both surface and groundwater resources management. However, it must be pointed out that no special regulation on groundwater has been proposed. Another major problem is the overlapping of the responsibility between different state authorities within a same country (Table 5).

Despite the various views and opinions of the parties involved, cooperation in transboundary water resource management in the ADRB has made significant steps forward over the last ten years (UNDP 2007). A certain consensus on the principle of reasonable and equitable sharing of water in accordance with the adopted regional agreements has already been achieved. However, there is still a lack of coordination and inconsistency in water use priority that leads to losses of the limited water resource, aggravation of tension and threat of conflict (Wegerich 2007). In order to fully cooperate, the countries involved must have confidence in each other and be prepared to compromise both in the area of their own interest and in the interest of the social and environmental needs of the region.

\section{CONCLUSION}

Although water supply was formerly centrally organised, since independence in 1991 the CAR and Afghanistan have continued their dispute on meeting their individual and 
increasing water demands. Since then, the lack of water has gradually devastated the irrigation-dependent cotton, winter wheat and other major crop production. In addition, the lack of water has engendered the ecological catastrophe of the Aral Sea Basin, at the tail end of both Amu Darya and Syr Darya.

Groundwater can be a strategic resource for these landlocked countries not only for drinking but also for agricultural production and environmental issues as demonstrated by Jarsjo and Destouni (2004). The lessons learned from the 1998-2001 droughts have proved the feasibility of groundwater developments in lower reaches of Amu Darya and elsewhere in the basin. And even if poor quality of the Amu Darya River has been observed both in quality and quantity in recent years, groundwater can still be reasonably exploited in many places were water salinity remains acceptable.

There is tendency for substantial unregulated groundwater withdrawal in the basin by farmers and populations for various purposes as an alternative source of water for irrigation. Historically, the agriculture sector has a very heavy weight on the basin country economies in terms of employment, financial revenues and food security. Thus for many good reasons the development of groundwater use is inevitable and better management strategies and cooperation between the different partners involved is necessary. Unfortunately the intricate management system of groundwater in the basin countries in terms of engineering infrastructure and institutional coordination is inadequate and States are financially totally unable to come over and to prevent the physical deterioration of hydraulic structures and to maintain an efficient water supply on large scale. In addition, transboundary agreements on joint utilization of groundwater resources are weak and fragmented in terms of regulation and institution levels.

\section{Acknowledgements}


The authors would like to thank the French Embassy in Tashkent for supporting the FrenchUzbek cooperation in the field of water sciences. This study has also been supported by INTAS fellowship Nr. 04-83-3665 and by the French Foreign Ministry of Foreign Affairs via the Eiffel fellowship program No. 530909C.

\section{References}

Aizen EM, Aizen VB, Melack JM, Nakamura T, Ohta T (2001) Precipitation and atmospheric circulation patterns at mid-latitudes of Asia. Int. J. Climatol. 21: 535-556

Babaev A, Kolodin M (1995) The water resources of Turkmenistan. Problems of Desert Development, 4, 18-23.

Babaev A, Kolodin M (1997) The use of the local water resources of Turkmenistan. Problems of Desert Development, 2, 3-7.

Babu S, Toshmatov A (2000) Food policy reforms in Central Asia: Setting the research priorities. International Food Policy Research Institute, Washington DC, USA

Banks D, Soldal O (2002) Towards a policy for sustainable use of groundwater by nongovernmental organisations in Afghanistan. Hydrogeology Journal, 10:377-392

Borisov VA (1990). Groundwater resources and their use in national economy. Published by "Fan”, Tashkent, 67p.

Borisov V A, Vavlenko LI, Musaev TP, Sultanova DG (2002) Index assessment of quality of drinking groundwater of Uzbekistan. A paper presented at the Conference on Drinking Water Supply and Ecology, Tashkent, Uzbekistan.

Chembarisov EI, Bakhritdinov BA (1989) Hydrochemistry of river and drainage water resources of Central Asia. Published by “Ukituvchi”, Tashkent, 55p. 
Crosa G, Froebrich J, Nikolayenko V, Stefani F, Galli P, Calamari D (2006a) Spatial and seasonal variations in the water quality of the Amu Darya River (Central Asia). Water Research 40, 2237-2245.

Crosa G, Stefani F, Bianchi C, Fumagalli A (2006b) Water security in Uzbekistan: implication of return waters on the Amu Darya Water Quality. Environ Sci \& Pollut Res 13, $37-42$.

FAO website. http://www.fao.org. Accessed on 15 November 2007.

Fuchinoue H, Tsukatani T, Toderich KN (2002) Afghanistan revival: irrigation on the right and left banks of Amu Darya. Discussion Paper No. 554. Kyoto Institute of Economic Research, edited by Kyoto University, Japan, 47p.

Gadalia A, Motelica-Heino M, Serra H, Abou Akar A, Jouin F, Charpy A (2005) Inorganic pollutants of the Syr-Daria River (Kazakh Priaralie). Tethys Geographical Research I, 79-92.

Heaven S, Koloskov GB, Lock AC, Tanton TW (2002) Water resources management in the Aral Basin: a river basin management model for the Syr Darya. Irrigation and Drainage, 51, 109-118.

Huneau F, Blavoux B, Bellion Y (2001) Differences between hydraulic and radiometric velocities of groundwaters in a deep aquifer: example of the Valréas Miocene aquifer (southeastern France). Comptes Rendus de l’Académie des Sciences - Series IIA - Earth and Planetary Science, 333, 163-170.

Ibragimov N, Evett SR, Esanbekov Y, Kamilov BS, Mirzaev L, Lamers JPA (2007) Water use efficiency of irrigated cotton in Uzbekistan under drip and furrow irrigation. Agricultural water management, 90, 112-120.

Jarsjo J, Destouni G (2004) Groundwater discharge into the Aral Sea after 1960. Journal of Marine Systems, 47, 109-120. 
Kazbekov J, Rakhmatullaev S, Huneau F, Le Coustumer P (2007) Types and hydrogeologic features of surface and groundwater interactions in Uzbekistan. Paper presented at the $35^{\text {th }}$ International Association of Hydrogeologists Congress, Lisbon, Portugal, 17-21 September 2007. CD of the Conference Proceedings, ISBN978-989-95297-3-1

Khatamov A (2002) Water resources management in Turkmenistan: current issues and problems. Paper presented at the Conference on Water Resources of Central Asia-Water, Almaty, Kazakhstan, 10-14 November 2002.

Kitamura Y, Yano T, Honna T, Yamamoto S, Inosako K (2006) Causes of farmland salinization and remedial measures in the Aral Sea basin, Research on water management to prevent secondary salinization in rice-based cropping system in arid land. Agricultural Water Management, 85, 1-14.

Kuchuhidze TV, Mavlonov AA, Krasnikov VV (2003) Lessons of drought in 2001 in Karakalpakistan. A paper presented at the Conference on Development of Systems on Rational Use of Surface and Groundwater Resources in Aral Sea Basin. Tashkent, Uzbekistan, 5-6 July 2003.

Létolle R, Mainguet M (1993) Aral. Springer-Verlag, Paris, 357p.

Masood A, Mahwash W (2004) Water resource development in Northern Afghanistan and its implications for Amu Darya Basin. World Bank Working paper No.36. Washington D.C., USA, 53p. ISBN 0-8213-5890-1.

Medecins Sans Frontieres (2001). Household Water Needs Assessment in Karakalpakistan, July-August 2001. Summary Report, Tashkent, Uzbekistan, 25p.

Mirzaev SS (1974). Groundwater reserves of Uzbekistan. Published by "Fan", Tashkent, 224p. 
Nezlin NP, Kostianoy AG, Lebedev SA (2004) Interannual variations of the discharge of Amu Darya and Syr Darya estimated from global atmospheric precipitation. Journal of Marine Systems, 47, 67-75.

Northey JE, Christen EW, Ayars JE, Jankowski J (2006) Occurrence and measurement of salinity stratification in shallow groundwater in the Murrumbidgee Irrigation Area, southeastern Australia. Agricultural Water Management, 81, 23-40.

O’Hara SL (1997) Irrigation and land degradation: implications for agriculture in Turkmenistan, central Asia. Journal of Arid Environments, 37, 165-179.

Orlovsky N, Orlovsky L (2002) Water resources of Turkmenistan: use and conservation. Paper presented at workshop on water, climate, and development issues in the Amu Darya basin, Philadelphia, USA.

Ostrovsky VN (2007) Comparative analysis of groundwater formation in arid and super-arid deserts (with examples from Central Asia and Northeastern Arabian Peninsula). Hydrogeology Journal, 15, 759-771.

Papa E, Castiglioni S, Gramatica P, Nikolayenko V, Kayumov O, Calamari D (2004) Screening the leaching tendency of pesticides applied in the Amu Darya Basin (Uzbekistan). Water Research, 38, 3485-3494.

Salimov T (2001) Management of Water Quality, Dushanbe, Tajikistan, 276p.

Shah T (2007) Groundwater: a global assessment of scale and significance. IWMI Report, Colombo, International Water Management Institute.

Shultz V (1949) Central Asian rivers. Published by “Nauka” Moscow, USSR, 69p.

Struckmeier WF, Gilbrich WH, Gun JVD Mauer T, Puri S, Richts A, Winter P, Zaepke M (2006) WHYMAP and the World Map of Transboundary Aquifer Systems at the scale of 1:50 000 000. UNESCO, $4^{\text {th }}$ World Water Forum, Mexico City, March 2006. 
Uhl VW (2003) Afghanistan: An overview of groundwater resources and challenges. Technical Report by Uhl, Baron, Rana \& Associates, Inc. Afghanistan Groundwater, Kabul, Afghanistan, 39p.

UNDP (2007) Water, critical resource for Uzbekistan’s future. UNDP Program, Tashkent, Uzbekistan, 121p.

UNESCO (2001) Internationally Shared (Transboundary) Aquifer Resources Management, their significance and sustainable management. IHP-VI, IHP Non Serial Publications in Hydrology SC-2001/WS/40, November 2001, UNESCO, Paris, 71p.

Water resources of USSR (1971) Amu Darya River Basin. Volume 14 Central Asia, issue 3, Published by “Gidrometeoizdat”, Saint-Petersburg, USSR, 471p.

Wegerich K (2007) A critical review of the concept of equity to support water allocation at various scales in the Amu Darya basin. Irrig Drainage Syst (2007) 21:185-195

Zaisheng H, Jayakumar R, Ke L, Hao W, Rui C (2008) Review on transboundary aquifers in People’s Republic of China with case study of Heilongjiang-Amur River Basin. Environmental Geology, 54:1411-1422. 


\section{Table list}

Table 1 Groundwater reserves and their use by states in ADRB in $\mathrm{km}^{3} /$ year (UNDP, 2007)

Table 2 Groundwater recharge and withdrawals in the ADRB (UNDP, 2007)

Table 3 Irrigated lands with high groundwater table level in ADRB, evolution from 1990 to 1999 (FAO, 2007)

Table 4 Main characteristics of agricultural sector of the ADRB countries (FAO, 2007)

Table 5 The different groundwater management organizations in ADRB

\section{Figure list}

Fig. 1: Map of the Amu Darya River Basin and location of main irrigation areas 


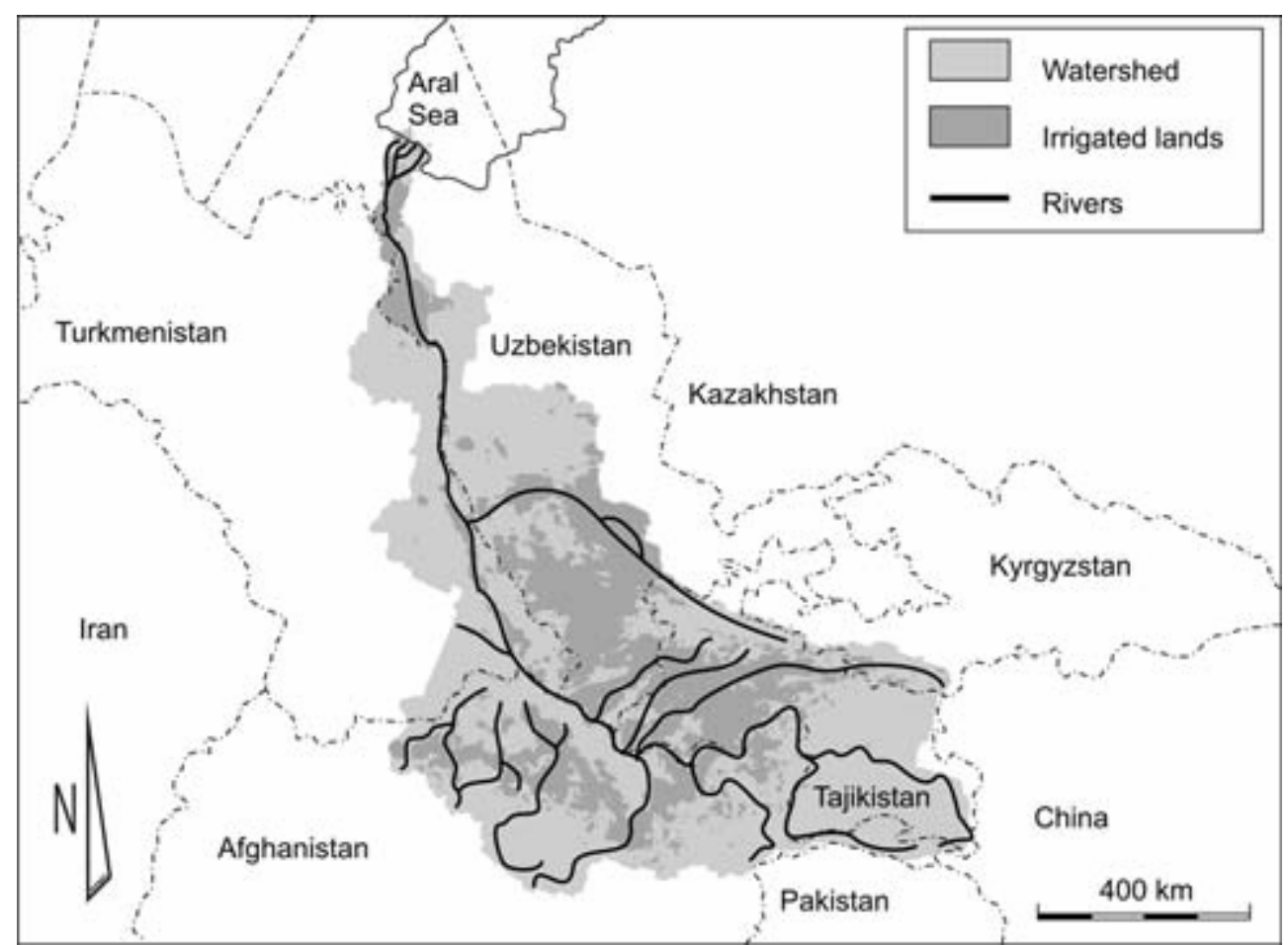


Table 1

\begin{tabular}{|c|c|c|c|c|c|c|}
\hline \multirow[t]{2}{*}{ Country } & \multirow{2}{*}{$\begin{array}{c}\text { Estimated } \\
\text { Regional } \\
\text { reserve }\end{array}$} & \multirow{2}{*}{$\begin{array}{l}\text { Approved } \\
\text { reserves for } \\
\text { use }\end{array}$} & \multirow{2}{*}{$\begin{array}{c}\text { Factual } \\
\text { withdrawal in } \\
1999\end{array}$} & \multicolumn{3}{|c|}{ Use Category } \\
\hline & & & & $\begin{array}{c}\text { Drinking } \\
\text { water } \\
\text { supply }\end{array}$ & Industry & Irrigation \\
\hline Tajikistan & 18.7 & 6.02 & 2.29 & 0.485 & 0.200 & 0.428 \\
\hline Turkmenistan & 3.36 & 1.22 & 0.457 & 0.210 & 0.036 & 0.15 \\
\hline Uzbekistan & 18.45 & 7.79 & 7.74 & 3.36 & 0.715 & 2.15 \\
\hline $\begin{array}{l}\text { Total, Aral Sea } \\
\text { Basin }\end{array}$ & 43.48 & 16.93 & 11.037 & 4.30 & 1.08 & 4.04 \\
\hline
\end{tabular}


Table 2

\begin{tabular}{|c|c|c|c|c|c|c|}
\hline \multirow[t]{2}{*}{ Country } & \multicolumn{2}{|c|}{$\begin{array}{c}\text { Average Annual Groundwater } \\
\text { Recharge } \\
\end{array}$} & \multicolumn{4}{|c|}{ Annual Groundwater Withdrawals } \\
\hline & $\begin{array}{l}\text { Total }\left(\mathbf{k m}^{3}\right) \\
\text { years vary }\end{array}$ & $\begin{array}{c}\text { Per Capita } \\
\left(\mathrm{m}^{3}\right) \text { Year } \\
2000 \\
\end{array}$ & Year & $\begin{array}{l}\text { Total } \\
\left(\mathbf{k m}^{3}\right)\end{array}$ & $\begin{array}{c}\text { Percentage of } \\
\text { Annual } \\
\text { Recharge } \\
\end{array}$ & $\begin{array}{c}\text { Per } \\
\text { Capita } \\
\left(\mathbf{m}^{3}\right) \\
\end{array}$ \\
\hline Afghanistan & 29.0 & 127 & - & - & - & - \\
\hline Tajikistan & 6.0 & 970 & 1994 & 2.3 & 37.7 & 398.7 \\
\hline Turkmenistan & 3.4 & 753 & 1994 & 0.4 & 11.9 & 100.3 \\
\hline Uzbekistan & 19.7 & 809 & 1994 & 7.4 & 37.6 & 334.3 \\
\hline
\end{tabular}


Table 3

\begin{tabular}{lccc}
\hline Country & $\begin{array}{c}\text { Areas with a water } \\
\text { table }<\mathbf{2 m} \\
\left(\mathbf{1 0}^{\mathbf{3}} \mathbf{h a}\right)\end{array}$ & $\begin{array}{c}\text { \% increase } \\
\mathbf{( 1 9 9 0 - 1 9 9 9 )}\end{array}$ & \\
\cline { 2 - 3 } & 1990 & 1999 & \\
\hline Tajikistan & 92 & 111 & 21 \\
Uzbekistan & 670 & 801 & 20 \\
Turkmenistan & 528 & 654 & 24 \\
\hline Total & $\mathbf{1 , 2 9 0}$ & $\mathbf{1 , 5 6 6}$ & $\mathbf{2 1}$ \\
\hline
\end{tabular}


Table 4

\begin{tabular}{lcccc}
\hline Country & $\begin{array}{c}\text { Share of Employment } \\
\text { in agriculture } \\
\text { (percent) }\end{array}$ & $\begin{array}{c}\text { Share of Agriculture } \\
\text { contribution to GDP } \\
\text { (percent) }\end{array}$ & $\begin{array}{c}\text { Irrigated } \\
\text { land } \\
\text { (million ha) } \\
\text { Amu Darya } \\
\text { Basin }\end{array}$ & $\begin{array}{c}\text { Share of irrigated to } \\
\text { the total cultivated } \\
\text { land } \\
\text { (percent) }\end{array}$ \\
\hline Afghanistan & 80 & 36,1 & 1,16 & 50 \\
Tajikistan & 67,2 & 23,6 & 0,43 & 17 \\
Uzbekistan & 44 & 27,3 & 2,48 & 80 \\
Turkmenistan & 48,2 & 16,7 & 1,74 & 96 \\
\hline
\end{tabular}


Table 5

\begin{tabular}{|c|c|c|c|}
\hline Country & Surface water & Groundwater & Other relevant agency \\
\hline Afghanistan & $\begin{array}{c}\text { Ministry of Water and } \\
\text { Power }\end{array}$ & $\begin{array}{l}\text { Ministry of Mines and } \\
\text { Industry }\end{array}$ & \\
\hline Tajikistan & $\begin{array}{l}\text { Ministry of Melioration } \\
\text { and Water Resources }\end{array}$ & $\begin{array}{c}\text { State Hydrologeological } \\
\text { Service }\end{array}$ & $\begin{array}{c}\text { Ministry of Environmental } \\
\text { Protection, Tajikistan Public } \\
\text { Water Supply Service }\end{array}$ \\
\hline Uzbekistan & $\begin{array}{l}\text { Ministry of Agriculture } \\
\text { and Water Resources }\end{array}$ & $\begin{array}{l}\text { State Committee on } \\
\text { Geology and Mineral } \\
\text { Resources }\end{array}$ & $\begin{array}{c}\text { State Committee on Safety in } \\
\text { Industry and Mining for Thermal } \\
\text { and Mineral Waters }\end{array}$ \\
\hline Turkmenistan & $\begin{array}{l}\text { Ministry of Land } \\
\text { Reclamation and Water } \\
\text { Resources }\end{array}$ & Ministry of Geology & $\begin{array}{l}\text { Ministry of Environmental } \\
\text { Protection }\end{array}$ \\
\hline
\end{tabular}

